\title{
Increased nitrosative/oxidative stress lowers myocardial protein kinase $G$ activity in heart failure with preserved ejection fraction
}

\author{
Loek van Heerebeek ${ }^{1,2^{*}}$, Nazha Hamdani ${ }^{1}$, Inês Falcão-Pires ${ }^{3}$, Adelino F Leite-Moreira ${ }^{3}$, Mark PV Begieneman ${ }^{4}$, \\ Jean GF Bronzwaer ${ }^{5}$, Jolanda van der Velden ${ }^{1}$, Ger JM Stienen ${ }^{1}$, Gerrit J Laarman', Aernout Somsen², \\ Freek WA Verheugt ${ }^{2}$, Hans WM Niessen ${ }^{4}$, Walter J Paulus ${ }^{1}$
}

From 6th International Conference on cGMP: Generators, Effectors and Therapeutic Implications Erfurt, Germany. 28-30 June 2013

\section{Background}

Prominent features of myocardial remodeling in heart failure with preserved ejection fraction (HFPEF) are high cardiomyocyte resting tension $\left(\mathrm{F}_{\text {passive }}\right)$ [1-4] and cardiomyocyte hypertrophy [2]. In experimental models, both reacted favorably to raised protein kinase G (PKG) activity $[4,5]$. The present study assessed myocardial PKG activity, its downstream effects on cardiomyocyte $F_{\text {passive }}$ and cardiomyocyte diameter, and its upstream control by cyclic guanosine monophosphate (cGMP), nitrosative/ oxidative stress, and brain natriuretic peptide (BNP). To discern altered control of myocardial remodeling by PKG, HFPEF was compared with aortic stenosis and HF with reduced EF (HFREF).

\section{Results}

Patients with HFPEF $(n=36)$, AS $(n=67)$, and HFREF $(n=43)$ were free of coronary artery disease. More HFPEF patients were obese $(\mathrm{P}<0.05)$ or had diabetes mellitus $(\mathrm{P}<0.05)$. Left ventricular myocardial biopsies were procured transvascularly in HFPEF and HFREF and perioperatively in aortic stenosis. $\mathrm{F}_{\text {passive }}$ was measured in cardiomyocytes before and after PKG administration. Myocardial homogenates were used for assessment of PKG activity, cGMP concentration, proBNP-108 expression, and nitrotyrosine expression, a measure of nitrosative/oxidative stress. Additional quantitative immunohistochemical analysis was performed for PKG activity and nitrotyrosine expression. Cardiomyocyte $\mathrm{F}_{\text {passive }}$ was higher in HFPEF

\footnotetext{
* Correspondence: L.vanheerebeek@vumc.nl

'Department of Physiology, Institute for Cardiovascular Research, VU Medical Center, Amsterdam, The Netherlands

Full list of author information is available at the end of the article
}

$\left(7.6 \pm 0.4 \mathrm{kN} / \mathrm{m}^{2}\right)$ than in AS $\left(3.4 \pm 0.2 \mathrm{kN} / \mathrm{m}^{2} ; P<0.001\right)$ and in HFREF $\left(5.1 \pm 0.2 \mathrm{kN} / \mathrm{m}^{2} ; P<0.001\right)$. In-vitro administration of PKG acutely lowered cardiomyocyte stiffness in all groups with the largest decrement in $\mathrm{F}_{\text {passive }}$ in DHF patients. PKG activity in myocardial tissue homogenates was significantly lower in HFPEF $(5.11 \pm 0.62 \mathrm{pmol} / \mathrm{min} /$ $\mathrm{mg})$ than in both AS $(9.18 \pm 0.64 \mathrm{pmol} / \mathrm{min} / \mathrm{mg} ; P<0.01)$ and HFREF $(11.51 \pm 2.0 \mathrm{pmol} / \mathrm{min} / \mathrm{mg} ; P<0.001)$. Immunohistochemical determination of myocardial PKG activity by pVASP/VASP ratio provided confirmatory evidence as it was also significantly lower in HFPEF $(0.70 \pm 0.03)$ than in both AS $(0.84 \pm 0.02 ; P<0.001)$ and HFREF $(0.85 \pm 0.03$; $P<0.001)$. Lower PKG activity in HFPEF than in aortic stenosis or HFREF was associated with higher cardiomyocyte $\mathrm{F}_{\text {passive }}(\mathrm{P}<0.001)$ and related to lower cGMP concentration $(\mathrm{P}<0.001)$ and higher nitrosative/ oxidative stress $(\mathrm{P}<0.05)$. Reduced PKG activity and lower myocardial cGMP concentration in HFPEF did not result from altered myocardial sGC or PDE5A expression, which was similar in all groups nor from unequal BNP expression, which was comparable in HFPEF and AS. The downregulated cGMP-PKG signaling in HFPEF was therefore related to low myocardial nitric oxide bioavailability because of high nitrosative/ oxidative stress.

\section{Conclusion}

Low myocardial PKG activity in HFPEF was associated with raised cardiomyocyte $\mathrm{F}_{\text {passive }}$ and was related to increased myocardial nitrosative/oxidative stress. The latter was probably induced by the high prevalence in HFPEF of metabolic comorbidities. Correction of myocardial PKG activity could be a target for specific HFPEF treatment. 


\section{Authors' details}

'Department of Physiology, Institute for Cardiovascular Research, VU Medical Center, Amsterdam, The Netherlands. ${ }^{2}$ Department of Cardiology, Onze Lieve Vrouwe Gasthuis, Amsterdam, The Netherlands. ${ }^{3}$ Department of Physiology and Cardiothoracic Surgery, University of Porto, Portugal. ${ }^{4}$ Department of Pathology, Institute for Cardiovascular Research, VU Medical Center, Amsterdam, The Netherlands. ${ }^{5}$ Department of Cardiology, Institute for Cardiovascular Research, VU Medical Center, Amsterdam, The Netherlands. ${ }^{6}$ Department of Cardiology, TweeSteden Hospital, Tilburg, The Netherlands.

Published: 29 August 2013

\section{References}

1. Borbély A, van der Velden J, Papp Z, Bronzwaer JG, Edes I, Stienen GJ, Paulus WJ: Cardiomyocyte stiffness in diastolic heart failure. Circulation 2005, 111:774-781.

2. van Heerebeek L, Borbély A, Niessen HW, Bronzwaer JG, van der Velden J, Stienen GJ, Linke WA, Laarman GJ, Paulus WJ: Myocardial structure and function differ in systolic and diastolic heart failure. Circulation 2006 , 113:1966-1973.

3. van Heerebeek L, Hamdani N, Handoko ML, Falcao-Pires I, Musters RJ, Kupreishvili K, ljsselmuiden AJ, Schalkwijk CG, Bronzwaer JG, Diamant M, Borbély A, van der Velden J, Stienen GJ, Laarman GJ, Niessen HW,

Paulus WJ.I: Diastolic stiffness of the failing diabetic heart: Importance of fibrosis, advanced glycation end products, and myocyte resting tension. Circulation 2008, 117:43-51.

4. Borbély A, Falcao-Pires I, van Heerebeek L, Hamdani N, Edes I, Gavina C, Leite-Moreira AF, Bronzwaer JG, Papp Z, van der Velden J, Stienen GJ, Paulus WJ: Hypophosphorylation of the stiff N2B titin isoform raises cardiomyocyte resting tension in failing human myocardium. Circ Res 2009, 104:780-786

5. Krüger $M$, Kötter $S$, Grützner $A$, Lang $P$, Andresen $C$, Redfield $M M$, Butt $E_{\imath}$ dos Remedios CG, Linke WA: Protein kinase $G$ modulates human myocardial passive stiffness by phosphorylation of the titin springs. Circ Res 2009, 104:87-94.

doi:10.1186/2050-6511-14-S1-O2

Cite this article as: van Heerebeek et al: Increased nitrosative/oxidative stress lowers myocardial protein kinase $\mathrm{G}$ activity in heart failure with preserved ejection fraction. BMC Pharmacology and Toxicology 2013

14(Suppl 1):O2.

\section{Submit your next manuscript to BioMed Central and take full advantage of:}

- Convenient online submission

- Thorough peer review

- No space constraints or color figure charges

- Immediate publication on acceptance

- Inclusion in PubMed, CAS, Scopus and Google Scholar

- Research which is freely available for redistribution

Submit your manuscript at www.biomedcentral.com/submit 